\title{
環境を考慮した製品の材料選択
}

\author{
芝池成人
}

松下電器産業株式会社くらし環境開発センター

J. Japan Inst. Metals, Vol. 65, No. 7 (2001), pp. 548-556

Special Issue on Ecomaterials Selection

(C) 2001 The Japan Institute of Metals

\section{Materials Selection for Environmentally Conscious Products}

\author{
Narito Shibaike \\ Human Environment Development Center, Matsushita Electric Industrial Co., Ltd., Kawasaki 214-8501
}

A rationalized methodology focusing on environmentally conscious materials selection for product design is described. This is a well-tailored application of the famous methodology for materials selection in mechanical design built by M. F. Ashby. A new value, environmental performance, is defined as the 'product performance per its environmental impact' in order to make a productive method, and is introduced into practical design process as well as a conventional value, cost performance. A case study on materials selection for TV's front cabinet is presented to show the method's effectiveness. According to the study magnesium alloys can be used for the component instead of the conventional material, polystyrene-fireproof in compound aspects of performance, cost and impact. An environmental impacts database of engineering materials to support the methodology is quite important and being created. A further approach on the development of a tool using a trial database for the efficient evaluation of materials is also presented. This software has a couple of benefits for average designers such as automatically creating of the performance indices and value functions, and its menu system to designate the design and value conditions is really easy and swift to use even if not having professional knowledge. The case study on head arms of hard disk drives makes it clear that the tool is valuable to create green products, particularly in the early stage of design process.

(Received January 24, 2001; Accepted February 15, 2001)

Keywords: materials selection methodology, environmentally conscious products, environmental performance, value function, environmental impacts database, materials evaluation tool

\section{1. は じめに}

従来，工業製品に用いられる材料の選定にあたっては，そ の製品が必要とする機能を最低のコストで実現する材料，あ るいは容認しうるコスト内で最高の特性を有する材料が選ば れてきた. 所謂コストパフォーマンスの最も優れた材料が一 義的に選定され，そのための材料評価手法が確立された．コ ストには材料の購入価格に加え後加工や表面処理等にかかる 費用も組み込まれるが，材料の違いによるコスト差が顕著に 見られなかったり比率が小さかったりと，材料原価で評価し て特に問題のない場合も多い。したがって，候補となる材料 の購入価格と特性とを比較分析すれば一応の目的は達せられ た.しかし近年では, 製品の「環境との調和」への配慮が不 可欠となり，特に材料はその製造，製品への加工，製品とし ての利用, 廃棄など地球環境に対して多方面で影響を及ぼす という認識から，材料選択のための新しい評価尺度として製 品の環境調和性を考慮する必要が生じてきたのである.

環境に配慮した工業製品に用いる材料の選定に関する事例 研究も多く見られるようになった ${ }^{1-6)}$.これらの殆どは製品 の LCA (Life Cycle Assessment)を実施して環境に与える影 響を定量化し，この環境負荷量が最小になるように材料を選 定する手法を試みているが，材料選択の 2 本の基軸となる
ベきコストパフォーマンスと環境調和性との関連については 具体的な提示がなされていない。これは，まず「環境調和性」 という尺度の定義が不明確であり, 当然の結果として両者を 同時に評価する手法が確立されていないことに起因する。 た, LCAによる分析結果を重視すると, 特に家電製品や産 業機械のようにその使用に際してエネルギーを消費する類の 工業製品については，材料や製造プロセスの最適化よりも製 品使用時の省エネルギー化を進める方が有効であるという結 論になる場合が多く，材料選択の重要性を見落とす可能性も あるので注意が必要である.

一方, 製品設計全般に関わる方法論の開発も盛んで, リサ イクルやリユースを考慮する, $\mathrm{CO}_{2}$ の排出量を抑える, 易 解体性を優先する, といった環境配慮型の各種概念をソフト ウェア上に構築して製品のライフサイクル全体を検討した り, 安全性や循環性に立脚した新しい評価指標を提案して設 計解を導出する試みが主流になっている7-12). これらの中に は, 製品の性能と環境への影響を同時に評価した例が徐々に 見られるようになってきているが11,12), 具体的な製品開発を 想定して，コストも視野に入れたシステマティックな評価を 実施している例はまだ少ない.

そこで本報告では, 材料選択の新しい評価尺度となる環境 調和性を明確に定義して, 従来からの尺度であるコストパフ オーマンスと同様の合理的な評価を可能とし, さらに両者を 
総合して材料選択の最適化を可能とする実践的な手法につい て概説し, 具体的な適用事例を紹介する. また, データベー スの拡張や手法のツール化による材料選択方法論の高度化お よび普及促進の試みについても併せて報告する.

\section{2. 環 境 調 和 性}

同じ材料を用いても, 用途, 形態, 使用頻度, 使用量等に よって製品の環境との調和度合は変化すると考えられる. る材料の環境負荷量 (資源の枯渴, 材料製造時のエネルギー 消費や $\mathrm{CO}_{2}$ 等の排出によって引き起こされる地球温暖化, 大気污染等の環境への影響を定量化, 指標化した各材料固有 の数值データ)が候補材料中で最小であっても, 製品に採用 された時にその環境調和性が単純に最大になるとは限らない であろう。環境負荷量はあくまでも材料の一側面を示すデー タに過ぎないのであり, 製品に利用する際に重視される材料 特性の考慮なしに議論されるべきではない。言い換えれば, 製品の環境調和性と材料の環境負荷量とを結びつけるのが 「設計」である。コストパフォーマンスが単なる材料物性值 と材料コストとの比ではなく, 設計を介して得られる製品と しての性能と材料コストとの相対的な価值の比較であると定 義できるのなら, 環境調和性についてもその対比において同 様の定義が可能である. つまり，工学的な尺度を基準に評価 することを前提にすれば，

環境調和性 $=$ 製品としての性能 $/$ 材料の環境負荷量 となる.この定義を用いて材料選択を進めるには, 材料工学 と設計工学に裏付けられた新しい設計論の体系的な確立が必 要と考えられるが, 機械系技術者を中心とする設計作業での 材料選択に対しては, 新手法の構築に必要な基礎理論が既に 確立されているのである.

機械設計における材料の選択手法は，英国ケンブリッジ大 学の Ashby によって建設された ${ }^{13-15)}$. ここでは設計要求を 分析し明確で合理的な材料選択を実現する方法論が高度に完 成されており, 設計対象も力学的, 熱的, 電気的, 複合制約 等に対応できるなど応用範囲が非常に広い. なかでもこの方 法論で用いられる材料選択チャートは Ashby maps と呼ば れ, 世界中の大学や研究機関で利用されている. そこで, こ の著名な材料選択方法論に環境調和性の概念を導入し, 生産 現場の設計プロセスを射程に捉えた「環境調和性を考慮した 材料選択方法論」が提案され, ケーススタディによりその有 効性が確認された ${ }^{16-18)}$. さらに, 方法論の基盤となる材料 データベースの拡張や手法のツール化に取り組むことで, 手 法の高度化と現場への普及が多方面で進められている ${ }^{19,20)}$. 以下にその概要を述べる.

\section{3. 環境調和性を考慮した材料選択方法論}

\section{1 材料選択方法論の基本}

Ashby の材料選択方法論は設計先導型であり，その基本 的な理論は性能指標と材料選択チャートで理解され る ${ }^{13-15)}$. 性能指標とは, 設計対象に要求される機能々制約 条件を用いて目的関数を作成し, そこから材料の属性に関連
するパラメータを抽出して構成した指標であり，機械設計の 諸要件を勘案しつつ材料の特徵を評価する上で非常に効果的 である。具体的には, 製品の使用形態(連結部材, 支柱, 回 転シャフト, 断熱壁, 変圧コイル等) と性能仕様 (剛性, 強 度, 断熱特性, 導電性, 耐熱衝撃性等) 加得られる構成方 程式を用いて, 目的関数(質量, コスト, 固有振動数, 熱容 量, 磁束密度等を求める支配方程式)内の自由变数(材料の厚 み, 幅, 直径等)を消去して作成する. 材料選択チャートは, 2 種類の材料物性值あるいは関数化された材料特性を X 軸, $\mathrm{Y}$ 軸に配した両対数グラフ上に，各材料をそのデータの幅 を示す楕円でプロットしたものである.

Fig. 1 に性能指標と材料選択チャートとの関連を示す. 典 型的な例として, 材料物性值 $P_{1}$ および $P_{2}$ (図では密度 $\rho$ お よびヤング率 $E$ ) から構成される性能指標 $M$ を考える.こ の $P_{1}$ および $P_{2}$ を $\mathrm{X}$ 軸および $\mathrm{Y}$ 軸に配した両対数グラフ上 では性能指標 $M$ は斜線として表される。なぜなら，簡単な 性能指標は通常以下のような形をしているからである.

$$
M=\frac{P_{2}^{n}}{P_{1}}
$$

この式の両辺の対数をとって変形すれば,

$$
\log P_{2}=\frac{1}{n}\left(\log P_{1}+\log M\right)
$$

となるので, 両対数グラフにおける斜線の傾き $1 / n$ が $P_{1}, P_{2}$ の関係を示し，その位置は $M$ の值で決定される．斜線を平 行移動すれば $M$ が変わる.この斜線を選択可能な材料が存 在するエリア内で $M$ の最適値(通常は最大值か最小值に設定 される)に移動させれば最適な材料が見つけられる. Fig. 1 の例では材料の種類毎にデータが太線で囲まれており，ま た，破線で軽量かつ堅牢な部材を選択するための性能指標が 提示されている. 図に見られるように，力学的制約を考慮す る場合では性能指標の傾きが設計条件(断面の形状や荷重の 負荷様式)により複数種類存在する.

この性能指標と材料選択チャートを用いた選択手法は複合 目的，すなわち一度の設計に抢いて複数の関連する目的を達 成しようとする場合にも適用できる ${ }^{15)}$. 例えば，冷蔵庫の 断熱材料を選択する例について考察する（解析の詳細は他の 文献16)を参照して戴きたい)。設計者は，材料コストも最小 にしたいし，使用中に冷蔵庫の断熱壁を通して散逸するエネ ルギーロスも最小にしたい，と考えるだろう。このとき，ま ず材料コスト (質量に単位質量あたりの材料価格 $C_{\mathrm{m}}$ を乗じ て求められる)を算出するための目的関数から第 1 の性能指 標 $M_{1}$ が構成される. 次に，エネルギーロスを算出するため の目的関数から第 2 の性能指標 $M_{2}$ が同様に構成され，千 ヤートを用いて $M_{1}, M_{2}$ が比較される．材料の選択は, Fig. 2 に示すように，両対数グラフ上に 2 つ目的を総合した等 高線を描くことで実行される.この曲線は, 数学的には極め て単純な形をした以下の関数 $V$ の等值包絡線を示している.

$$
V=M_{1}+C_{\mathrm{E}} M_{2}
$$

ここで $C_{\mathrm{E}}$ は適切に選ばれた変換(結合) 係数である. 一般的 には重み付腚数とも考えられるし，さらに正確に言うなら ば，第 1 の目的と第 2 の目的の相対的な価值を示してい る。この例であれば，エネルギーロスを $C_{\mathrm{E}}$ でコストに関連 


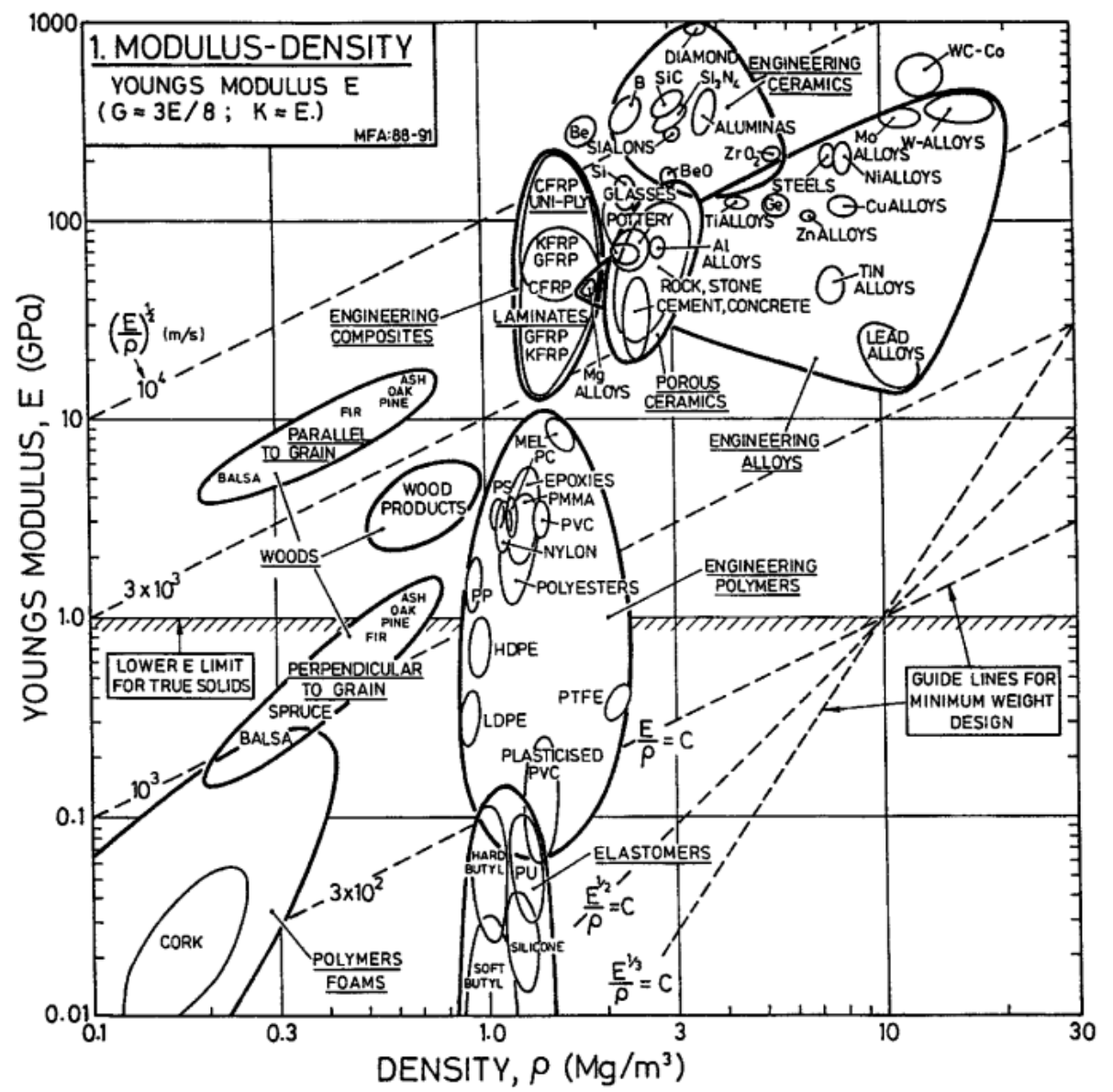

Fig. 1 Ashby's materials selection chart (From the reference $\left.{ }^{14)}\right)$.

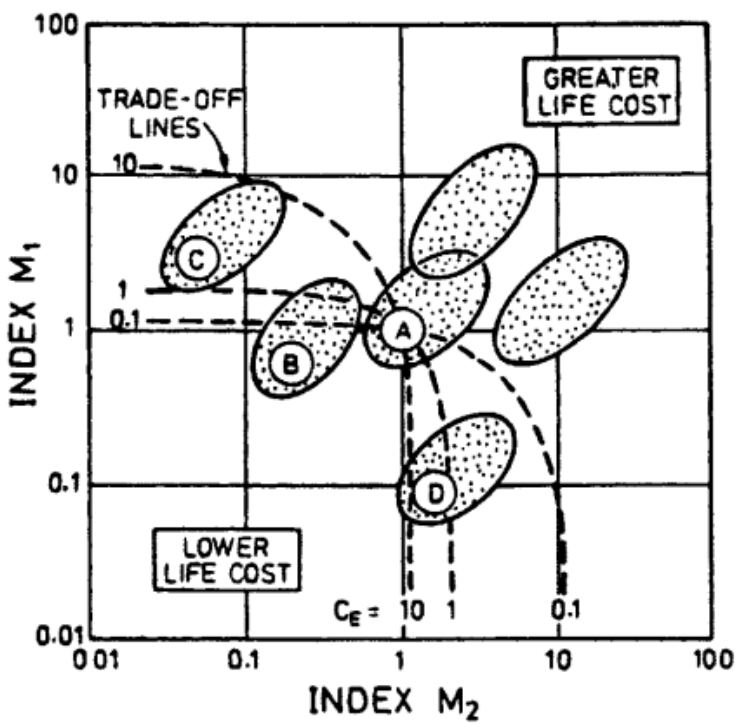

Fig. 2 Ashby's materials selection chart for compound objectives (From the reference ${ }^{15)}$ ).

付ければ全寿命でのコストが推定できることになる， $C_{\mathrm{E}}$ を 単位エネルギー消費量あたりの電気代とし， $M_{1}, M_{2}$ をうま く設定すれば $V$ は全寿命でのコストを示唆するだろう。つ まり，等高線上にあるすべての材料は，基準となる材料(図 のA）と同じ価値(全寿命でのコストに比例)を有している.
曲線より左下に存在する材料 $\left(C_{\mathrm{E}}=10\right.$ なら B 抢よび $\mathrm{C}, C_{\mathrm{E}}=$ 0.1 なら B 抢よび $\mathrm{D})$ は，基準材料より全寿命でのコストが 低くなると推定できる材料であり選択候補になる，右上にあ る材料はその逆である. 曲線の形状は $C_{\mathrm{E}}$ の值に依存してお り，その位置は $V$ の值で決定される。 この手法の特長は， 潜在的な材料価值をある条件下で明確かつ直感的に提示でき る点にある。

\section{2 環境調和性を合理的に考慮するための実践的な手法}

冷蔵庫の例では適切な変換係数によりエネルギーロスをコ ストに関連付け，初期コストと運用コストとの結合が試みら れた。この結合手法をコストパフォーマンスと環境調和性の 複合評価に応用する ${ }^{17,18)}$ ，時間軸を無視すれば，材料の断熱 効果を設計仕様と考えて熱伝導率 $\lambda$ と断熱壁の厚及 $t$, 冷蔵 庫内外の温度差 $\Delta T$ と密度 $\rho$ を用いた関数として表現で き, 初期コストを算出する目的関数に組み込むことが可能に なる.この結果, 材料物性值(ここでは熱伝導率 $\lambda$ 抢よび密 度 $\rho)$ と $C_{\mathrm{m}}$ との関連が簡単な数式で表せるので, コストと 材料特性を勘案した性能指標, すなわちコストパフォーマン 又指標 (以下 $\mathrm{CPI}$ )を構成することが可能になる.ささら，こ の CPI の $C_{\mathrm{m}}$ を単位質量あたりの環境負荷量 $C_{\mathrm{i}}$ に置き替え れば材料の使用量を考慮した環境負荷量を算出する目的関数 になるので，前述の定義を踏まえた環境調和性指標（以下 $\mathrm{EPI}$ も同時に構成可能となる. $C_{\mathrm{i}}$ を $C_{\mathrm{m}}$ と同様に扱って材 
料特性との関係を「単位環境負荷量あたりの性能」という観 点で指標化するのである (Ashby は以前より材料選択の将来 像を示すなかで環境への配慮による変革を論じ，その対応策 としてこの手法の原型を提示し ${ }^{21)}$, また green design とし て著作 ${ }^{14)}$ の中でも紹介している). 次に，この CPI と EPI, および先ほどの変換係数 $C_{\mathrm{E}}$ を用いて価值を示す関数 $V$ を作 成し，複合評価を行う(Ashby は前揭の著作の改訂版 ${ }^{22}$ にお いて，この応用手法についても例を挙げて言及している). この結果, 性能, コスト, 環境への影響を同時に考慮した材 料選択方法論が構築されるのだが，これを生産現場の設計プ ロセスに適用できるように，より実践的な手法として確立す るには，今少し工夫が必要である.

製品に要求される材料特性と価格 $C_{\mathrm{m}}$ とを数值化して CPI を計算すれば，従来からの実績や経験による評価が期待でき る。しかし，EPI に関しては今のところ明確な評価基準が 存在しない。環境への影響は一般的に定量化するのが難しい ということもあるが，仮に $C_{\mathrm{i}}$ が材料データとして十分に高 い精度を有していても, 評価基準となる閾值を設定するのは 困難である１つの候補としては，国や地方自治体の制定し ている環境基準や条例等が考えられるが，こうした数值は流 動的でかつ項目が限定されており, 統一された絶対的な基準 には程遠い。そこで本方法論では, 性能指標の絶対的な評価 ではなく，CPI や EPIの個別評価および複合評価のいずれ においても，基準となる材料に対する相対的な評価が実行さ れる. 設計において材料選択が全く白紙の状態で進められる ことは少なく, 通常は候補材料やその選定に関する知識や情 報がある程度備わっている，仕様変更に伴う設計変更や，環 境への配慮により設計を見直している状況を想定するなら ば，設計者はある特定の材料に対して，より優れた材料を探 すために材料選択という行為を遂行するのであるから，その 特定材料との相対評価ができれば十分であろう。また新たな 設計に扔いても, 標準的な材料との比較という形態で材料選 択を実行すれば事足りる，というのがその理由である.

コストパフォーマンスと環境調和性の複合評価は，それぞ れの支配方程式から構成した特殊な性能指標 CPI および $\mathrm{EPI}$ を適用し，チャート上の $\mathrm{X}$ 軸および $\mathrm{Y}$ 軸に各材料の データによる演算結果を投影した位相空間上で行われる.こ の場合の材料選択チャートも両対数グラフが便利である. 個 別評価も含めて, 常に一方向(例えば右上)が好ましい特性を 示すように決めておけば，いつでもチャートの一部(右上)に 望ましい材料が集まり，評価結果の理解も容易になるだろ う.ここでは既に性能指標から得られる斜線は存在せず, $\mathrm{CPI}$ を $P_{\mathrm{ct}}, \mathrm{EPI}$ を $P_{\mathrm{ev}}$ とした時に価值 $V$ を示す以下の評価 関数が曲線を描く.

$$
V=f\left(P_{\mathrm{ct}}\right)+C_{\mathrm{E}} f\left(P_{\mathrm{ev}}\right)
$$

2 つの性能指標 $P_{\mathrm{ct}}, P_{\mathrm{ev}}$ は, 前の記述から明らかなように, 基本的に同じ形をしているので，それぞれを関数 $f$ にって 変換した後, 変換係数 $C_{\mathrm{E}}$ に適切な換算值を代入し, $\mathrm{CPI}$ と EPIの次元を揃えて足しあわせる。これは，ある必要な性 能(材料特性)を得るために要する材料コスト (購入価格) と環 境コスト (環境負荷量をコストに換算したもの)の足し算であ り, ある要求性能と環境への配慮を満たすのに必要なトータ
ルコスト值 (以下 TCV) を示すと考えられる．この評価関数 を材料選択チャート上に描く際に基準となる材料上を通過す るように配置すれば，その基準材料と同じ TCV を示す「コ スト一定曲線」が得られる. 変換係数 $C_{\mathrm{E}}$ の值には, 例えば 環境税であったり，代替エネルギーの製造価格であったり， 安全に廃棄する費用であったり, 現在着目している環境負荷 量によって様々な換算值が想定できる.

こうした一連の手順を整理すると Fig. 3 に示すような形 式を構える。まず設計に対する要求事項の明確化を行い，設 計対象の機能，目的，制約条件を定める. 次に選択基準とな る 2 つの性能指標を導出するために設計対象の基礎解析か らコストと環境負荷量を算出する目的関数（または支配方程 式）を作成する。そして材料の属性に起因するパラメータを 抽出して CPI, EPI を構成し，サブチャートを用いて基準材 料に対する相対評価を個別に実施する，複合評価では，環境 負荷量をコストに関連付ける変換係数を用いて評価関数 (コ スト一定曲線)を作成し，設計要求を満たすためにその材料 が必要とする TCVをメインチャート上で基準材料に対する 相対評価として行う。チャートは基準材料の CPI, EPI, TCV によって, 図に示すように, 領域 $\mathrm{A}$ から領域 $\mathrm{E}$ に分類 される. 各領域内に位置する材料の選択に対する優先順位は 領域 $\mathrm{A}$ から領域 $\mathrm{E}$ の順になるが，領域 C と領域 D は状況に 応じて順序が逆転する. 制約条件が複数ある場合は, 以上の 手順を繰り返して最適な材料を絞り込む. 具体的な性能指標 の作成方法や材料選択の進め方については事例を用いて説明 する。

\section{3 方法論の適用事例一 TV のフロントキャビネット18)—}

TV のフロントキャビネットは内部に CRT を支持し, 安 価で見栄えがよく，かつ安全でなければならない。一般にプ ラスチック材料は然えやすく難然剤が添加されるため, 現行 材料である難然性ポリスチレン (以下 PS-F) は価格が高くリ サイクル率も低い。そこで環境を考慮したTVの実現に向 け, リサイクル性と堅牢性を向上させ, 安全性, 生産性, 軽 量性に配慮して，アルミニウム合金 (以下 $\mathrm{Al}$ ) とマグネシウ ム合金(以下 $\mathrm{Mg}$ )をフロントキャビネットの材料として採用

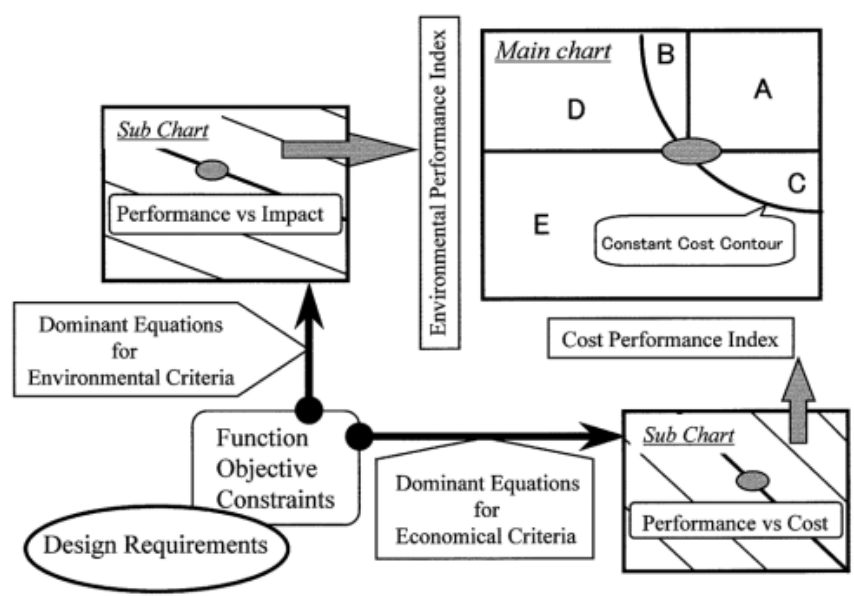

Fig. 3 Environmentally conscious materials selection methodology (From the reference $\left.{ }^{18}\right)$. 
可能か否かが評価の対象となった，まず，設計に対する要求 事項は以下のように設定された.

・機能 : 曲げモーメントに耐える軽い板材

・目的：材料のコストとエネルギー容量を最小にする

・制約条件：(1) CRT を支持する剛性

(2) 製造時に変形破壊しない強度

(3) 音声に影響を及ぼさない振動特性

(4) 内部温度の上昇を避ける放熱効果

ここでエネルギー容量とは，その材料を製造するのに必要な エネルギーとその材料自体に含まれるエネルギーの総和であ り，リサイクルを考慮しなければ，その材料を製品として使 用したことで地球上から消滅してしまうエネルギーの総量と 考えられる。使用するデータおよび材料選択チャートは

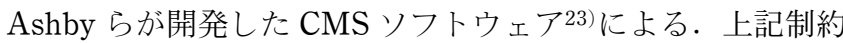
条件のうち，剛性に関する評価例を Fig. 4 を用いて紹介す る.

内蔵する CRT を支えるために，与えられた曲げモーメン 卜に耐える剛性が要求されるが，片持ち梁状態でその先端に 荷重がかかるものとする。この時，曲げモーメント $M$ に対 する歪み量 $\delta$ を与える弾性曲げの構成方程式は,

$$
\delta=\frac{l^{2}}{C_{1} E I} M
$$

である。ここで $C_{1}$ は荷重の設定で決まる定数， $E$ はヤング 率， $I$ は梁の断面 2 次モーメント， $l$ は梁の長さである. 梁 の断面が平板で厚みのみ可変であると仮定すると,

$$
I=C_{2} t^{3}
$$

である. $t$ は材料の厚み， $C_{2}$ は形状で決まる定数であるか ら，与えられた剛性を保持するのに必要な材料の質量 $W$ は,

$$
W=C_{3} t \rho=C_{3}\left(\frac{l^{2}}{C_{1} C_{2}}\right)^{1 / 3}\left(\frac{M}{\delta}\right)^{1 / 3} \frac{\rho}{E^{1 / 3}}
$$

となる.ここで $C_{3}$ は形状で決まる定数, $\rho$ は材料の密度で ある.この式から最小にすべき $W$ は， $\rho$ に比例し $E$ の $1 / 3$ 乗に反比例することがわかる. 他は全て形状に関する係数, または荷重や歪久量に対する設計仕様であり，この解析の範 囲内に招いては定数と考えて差し支えない.

この結果, $1 / \rho$ を $\mathrm{X}$ 軸, $E$ を $\mathrm{Y}$ 軸に配すると, 両対数グ ラフで基準材料上を通る傾き -3 の斜線が，基準材料である PS-F と同じ質量性能(単位質量あたりの剛性)を示す。図は 省略するが， Mg は $\mathrm{Al}$ や PS-Fより軽くて剛性の優れたキ ヤビネットになり得ることがわかる．ここで $\rho$ に $C_{\mathrm{m}}$ を乗ず ると, 剛性に関するコストパフォーマンスが評価でき, 眓の 右下にその結果が示されている. Al は PS-Fより優れてい るが， Mg は PS-F とほぼ同じかやや劣る程度である。一方， $\rho$ に材料の質量あたりのエネルギー容量 $q$ を乗ずると単位エ ネルギー容量あたりの剛性が評価できる．さらに各材料のリ サイクル効果 $R$ を乗ずればリサイクル性も考慮した環境調 和性が評価でき, 結果は図の左上に示されている. Al と $\mathrm{Mg}$ はともに PS-Fよりも環境に優しい材料である.

以上を総合し $\mathrm{CPI}\left(P_{\mathrm{ct}}\right), \mathrm{EPI}\left(P_{\mathrm{ev}}\right), \mathrm{TCV}(V)$ を以下のよ うに構成してコスト一定曲線を描くと，右上のメインチャー
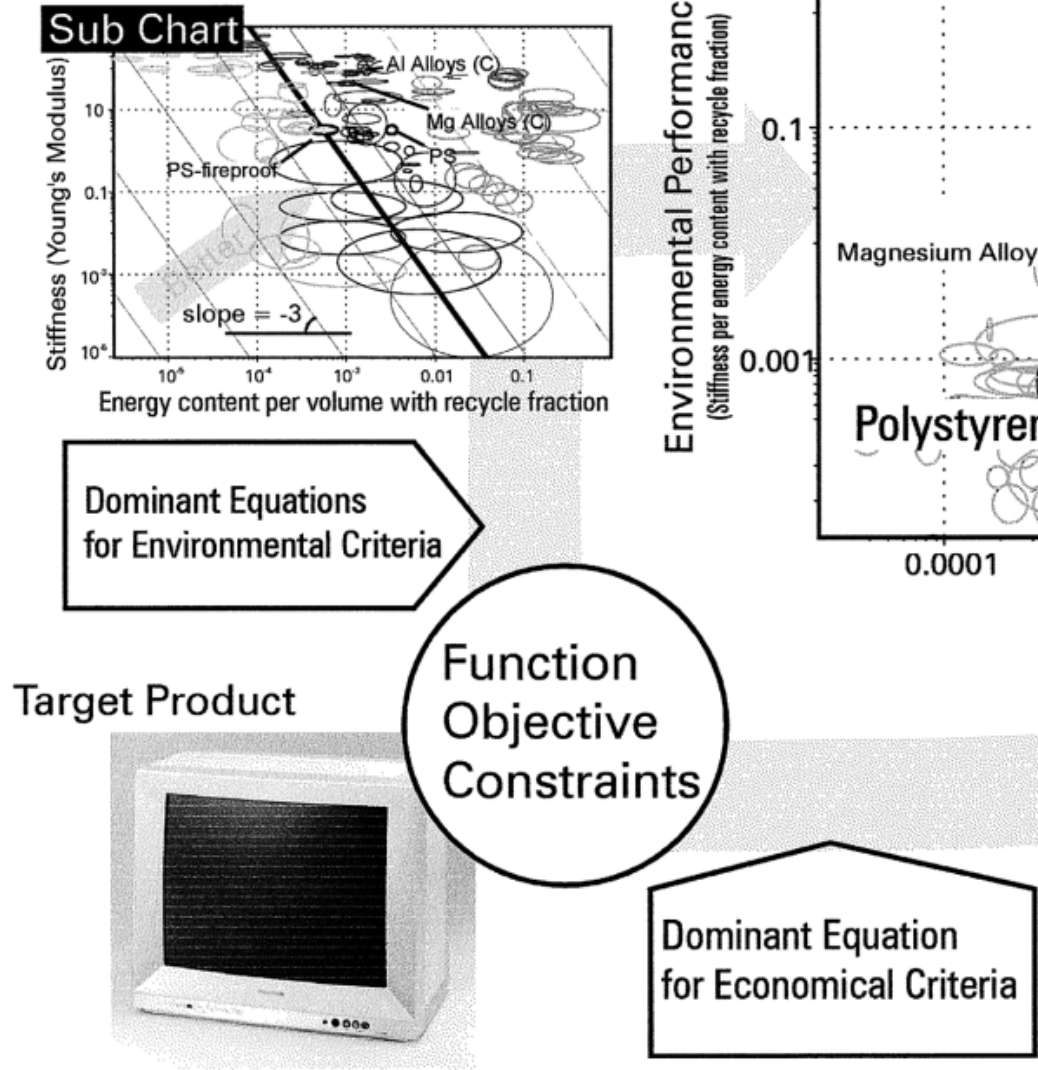

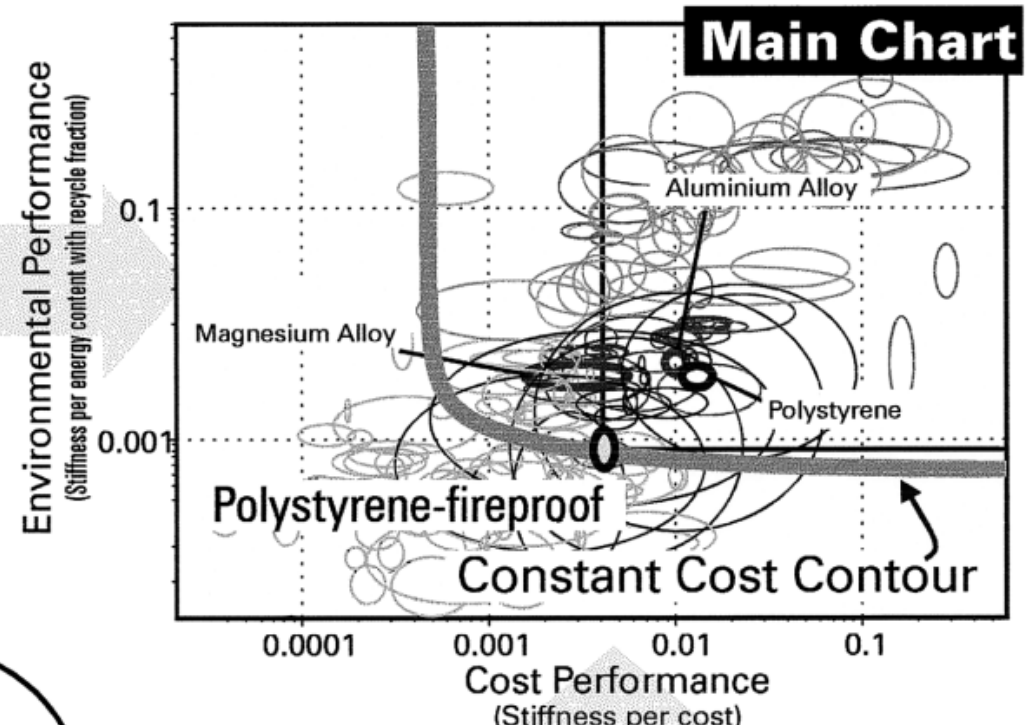

(Stiffness per cost)

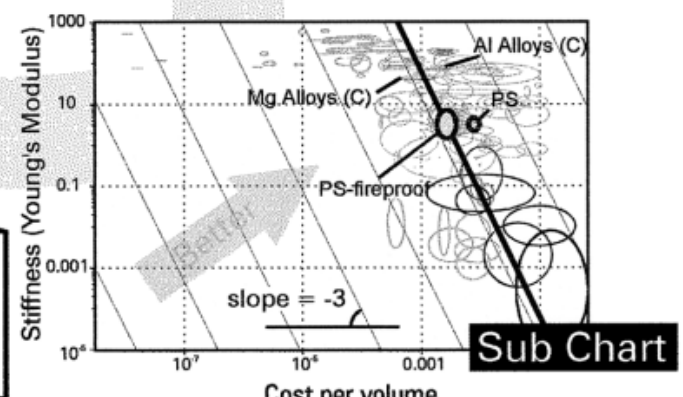

Fig. 4 Case study on materials selection for TV's front cabinet (From the reference ${ }^{17)}$ ). 


\section{Better}

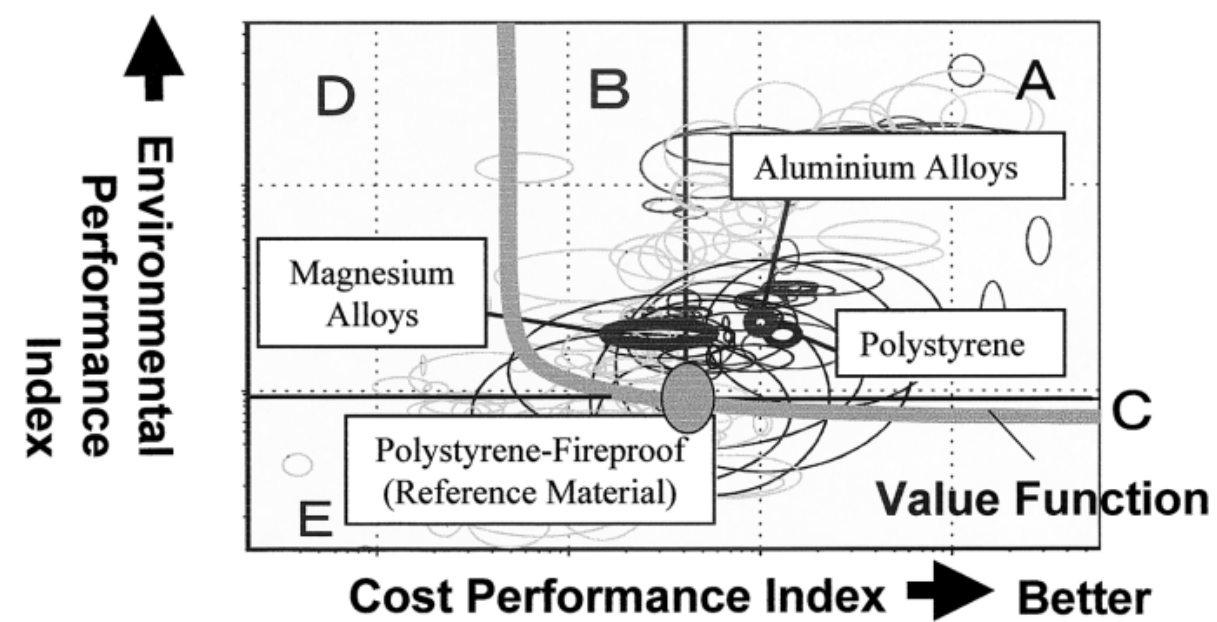

Fig. 5 Result of compound evaluation by cost and environmental performance indices in stiffness of materials for TV's front cabinet.

Table 1 Evaluation results of materials for TV's front cabinet (From the reference $\left.{ }^{18)}\right)$.

\begin{tabular}{|c|c|c|c|}
\hline & \multicolumn{2}{|c|}{ Comparison with polystyrene-fireproof } & \multirow{2}{*}{$\begin{array}{c}\text { Comparison between } \\
\mathrm{Al} \text { and } \mathrm{Mg} \\
\text { in unit mass }\end{array}$} \\
\hline & $\underset{\mathrm{Al}}{\text { Aluminium alloys }}$ & $\begin{array}{c}\text { Magnesium alloys } \\
\mathrm{Mg}\end{array}$ & \\
\hline Stiffness & Area A & Area B & $\mathrm{Mg}$ \\
\hline Strength & Area $\mathrm{A}$ & Area B & $\mathrm{Mg}$ \\
\hline Vibration & Area A & Area B & $\mathrm{Mg}$ \\
\hline $\begin{array}{l}\text { Heat } \\
\text { conduction }\end{array}$ & Area A & Area A & Equal \\
\hline
\end{tabular}

トが作成され，コストパフォーマンスと環境調和性を同時に 考慮した複合評価が可能になる. Fig. 5 にメインチャートに よる評価を解りやすく表示する.

$$
\begin{aligned}
& P_{\mathrm{ct}}=\frac{E^{1 / 3}}{\rho C_{\mathrm{m}}} \\
& P_{\mathrm{ev}}=\frac{E^{1 / 3}}{\rho C_{\mathrm{i}}}=\frac{E^{1 / 3}}{\rho q} R \\
& V=f\left(P_{\mathrm{ct}}\right)+C_{\mathrm{E}} f\left(P_{\mathrm{ev}}\right)=\frac{1}{P_{\mathrm{ct}}}+\frac{C_{\mathrm{E}}}{P_{\mathrm{ev}}}=\frac{\rho}{E^{1 / 3}}\left(C_{\mathrm{m}}+C_{\mathrm{E}} \frac{q}{R}\right)
\end{aligned}
$$

図では $\mathrm{Mg}$ は領域 B 内に存在しており, CPI で PS-F に若 干劣ってはいたが $\mathrm{EPI}$ では優れ, 変換係数 $C_{\mathrm{E}}$ にエネルギー の代償コスト（ここでは 1.6 円/MJ としている)を採用する と TCVに拈いて遜色のない材料となることがわかる。しか も質量性能では $\mathrm{Al}$ より優れている. したがって, 剛性に関 する評価としてリサイクル性, 堅牢性, 軽量性の点から評価 すると, Mg は PS-F に替わりうる材料であると判断される.

Table 1 に剛性, 強度, 振動特性, 放熱効果の各評価結果 を示した. 剛性以外の評価の詳細は他の文献18)を参照して 戴きたい，基準材料である PS-F に対する $\mathrm{Mg}$ の優位性は環 境コストを導入すれば明白になり，A1に対しては常に軽量 化の点で優っている. また， Mg は減衰効果において金属材 料中では出色であることからも, 環境配慮型 TVのキャビ ネット材料としての選択に正当性が認められる。ただし，こ
の判断にはリサイクル効果の考慮が前提条件となっている. 金属材料はプラスチック材料に比べて再利用やリサイクルに は向いている．耐久性はもちろん，再製造時に予想される高 温処理や溶剂処理はその顕著な例である。ささに，Al や $\mathrm{Mg}$ はリサイクル材の製造エネルギーがバージン材料の製造 時に比較して格段に小さく, 著しい効果がある.

\section{4. 環境負荷量に関するデータベース}

以上に説明した方法論の適用範囲を拡大し普及を促進する ためには，その基盤となるデータベース（材料物性值，価 格, 環境負荷量, 各種環境コスト等)の開発整備が重要であ る．ところが，環境負荷量については入手できるデータがま だ少なく，また市販データベース間での值のばらつきも見ら

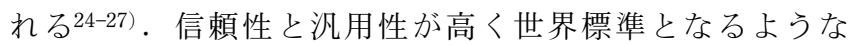
データベースの登場が待たれるところであるが，枠組みとし て以下のような観点で整理されたものが望ましい.

\section{1 省エネルギー性}

省エネルギーは多くの工業製品においてその使用中に重視 されるべきであると考えられているが，材料の選定時にも幾 つか考慮すべきデータがある。一次エネルギー容量 $[\mathrm{MJ} /$ $\mathrm{kg}$ ]はバージン材料を製造するのに必要なエネルギーとその 材料自体に含まれるエネルギーの総和である，金属ではほぼ 製造エネルギーに等しいと考えて良いが，高分子材料では材 料自体のエネルギーも無視できない。リサイクルをしなけれ ば，結果的にその材料を使用することで地球上から消え去る エネルギー量を示すと考えられる．二次エネルギー容量 $[\mathrm{MJ}$ $/ \mathrm{kg}]$ は資源の採掘や第一次的な製造エネルギー量を差し引 いた，リサイクル材料を念頭に置いたエネルギー容量であ る. 最低溶融エネルギー $[\mathrm{MJ} / \mathrm{kg}]$ はリサイクルエネルギー の目安となる材料の最低溶融エネルギーである．この数值が 大きいほど，材料としての再利用に必要なエネルギーも高く なる。 


\section{2 省資源性}

材料の使用という点で資源の枯渴は実感しやすい環境負荷 データである，埋蔵鉱量 $[\mathrm{Mt}]$ は存在が確認されており，現 在の技術で採掘が可能で，かつ経済的に見合うと考えられる 資源の埋蔵量をいう。年間生産高 $[\mathrm{Mt} / \mathrm{year}]$ は 1 年間の全世 界における資源の総生産量(製造量)であり，この值が小さい ほど考慮中の材料の使用による影響は大きくなり注意が必要 になる，資源枯渴指標 $[$ years $]$ は現在のペースで採掘を継続 した場合に資源が枯渴してしまうまでの年数をもとに算出さ れる指標で，考慮中の材料の使用量とは関係がない.

\section{3 低環境負荷性}

LCA 評価で低環境負荷性として重視される温室効果指 標，酸性化指標，大気污染指標，富栄養化指標等は各種排出 物の排出量と負荷ポテンシャルをもとに算出される. 二酸化 炭素 (温室効果指標に影響), 一酸化炭素 (大気污染指標に影 響), 塵埃 (大気污染指標に影響)，炭化水素 (大気污染指標に 影響), メタン(温室効果指標に影響), 窒素酸化物 (酸性化指 標, 大気污染指標, 富栄養化指標に影響), 硫黄酸化物 (酸性 化指標, 大気污染指標に影響) 等のデータは個別のデータも 重要だが，こうした指標に加工されてより大きな意味を持つ.

\section{4 安全性}

安全性は直感的な指標であるが，定量評価が難しく工学的 に扱いにくいデータである．特に毒性について人体への影響 まで考慮しようとすれば，量的な議論ではなく，採用か不可 かという程度の判断しかできないのが現状である. 鉛, カド ミウム，水銀，六価クロム，アスベスト， PCB, PVC 等は 最初から選択範囲外に位置付けておくべき材料である. もし そうしないのなら，材料選択の担当者はその科学的な根拠を 示さなくてはならない.

\section{5. 材料選択方法論の具現化ツール}

\section{1 選択基準の一般化}

環境調和性を考慮した材料選択方法論において性能指標と 評価関数の導出は最も重要なプロセスであるが，少なからず 専門的な知識を必要とするため, 方法論の適用はある程度の 限られた範囲においてのみ期待される。事実，Ashby らは 初心者向けに数多くのケーススタディを提示しているが，同 時に精密機器の振動や熱歪久等の問題では高度な解析が必要 となることも報告している28,29)。設計との関連に重きを扔い たエキスパートシステムとしての材料選択ソフトウェアで は，データおよびチャート作成に利用した前述の CMS とそ の発展型である $\mathrm{CES}^{30)}$ 以外には FUZZYMAT ${ }^{31)}$ 等が知ら れているが，通常の解析ソフトがそうであるように，いずれ もある程度の材料力学的知識を有する者でないと使いこなす のは難しい。しかし，環境問題は人類全てが直面しかつ緊急 を要する課題であり，その対策には従来の学問領域を越えた アプローチが必要とされ32)，また，限られた専門家のみで 対応できる状況にないことも明白である。したがって，たと
え高度な知識を有さずとも環境に考慮した製品の実現を可能 とするッールが今後必須になる，そのためには機能，目的， 制約条件によって明確になった設計要求をそのまま，あるい はよりブレークダウンして入力して材料選択ができるように 選択基準を一般化し，また，生産現場のニーズにも応えられ るような工夫が必要である.

CPI と EPI は製品質量 (の最小化)を目的関数とする性能 指標, すなわち質量性能指標 (以下 MPI) から求められる. MPI は製品の機能を実現する前提条件(断面形状と負荷様 式）と性能を拘束する制約条件で決定できる，例えば，断面 の幅と厚みの比が一定である場合, 断面積 $A$ は自由変数 (幅

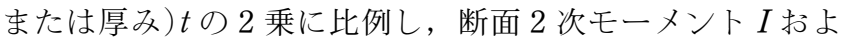
び断面ねじりモーメント $K$ は $t$ の 4 乗に比例するので, 結 局 $A$ は $I$ および $K$ の $1 / 2$ 乗に比例する. また，断面が矩形 で厚久の久可变であれば, $A$ は自由变数(厚み) $t$ に比例し, $I$ は $t$ の 3 乗に, $K$ は $t$ のほぼ 3 乗に比例するので, $A$ は $I$ および $K$ の $1 / 3$ 乗に比例する. 負荷様式についても, 荷重 の支持方法として通常考えられる軸方向荷重, 曲げモーメン ト，ねじりモーメント(トルク), また, 内外圧, そして特殊 な場合として座屈も考慮する必要があるだろう。したがっ て, 通常想定される断面形状と負荷様式をマトリックス状に 配して各制約条件毎の MPI をそれぞれ求めておき，与えら れた課題がどの条件に相当するかを決定して適用すれば，そ の都度面倒な解析をしなくても済む.

制約条件でも同様に想定される問題を予めパターン化して おくという対応が可能である. 応力や歪久等を扱う力学的制 約としては剛性, 強度, 振動, 弾性エネルギ一等に関する考 慮が必要だろうが，特に設計との関連が強いので断面形状や 負荷様式に注意しなくてはならない。熱の移動を伴う熱的制 約としては断熱効果, 熱容量, 熱膨張, 熱歪み等に関する考 慮が想定され，熱の移動方向に対する材料の厚久を一部考慮 する場合はあるが，断面形状や負荷様式による影響はない. 電気的制約としては導電性, 絶縁性, 誘電率等について拘束 され, 熱の場合と同様, 電流の移動方向に対する材料の厚み を一部考慮する. 力学的制約と熱的制約の複合的な制約とし て熱応力, 熱衝撃等についても考慮する必要があるだろう が，これらは材料特性のみで評価が可能であり設計との関連 がない. 上記の複合的制約のような場合や，全く拘束要素を 設定しない場合は MPI が定義できないので，材料の質量の みを考慮してMPI を密度 $\rho$ だけの関数として定義し, 別途 評価される，こうして設計条件を分解し予めMPI を求めて おけば， CPI， EPI および TCV を設計条件と評価条件とか ら自動的に創出して材料評価作業を迅速かつ正確に実行する ソフトウェアが実現できる19).

\section{2 評価条件の設定}

材料の評価には上記の設計条件とともに評価条件の設定が 必要になる．評価条件では考慮する環境負荷量の種類(環境 負荷因子)や基準となる材料の設定に加え，この基準材料に 対する増減の許容值を設定して評価の閾値をユーザが作成す る.このプロセスはユーザの裁量による評価を可能とするも のであり，画一的な評価に陥らないための重要なステップで 
ある. 例えば基準材料に対する質量の増減許容割合を決めれ ば，基準材料と同じ性能を維持する評価対象の各材料の質量 が，基準材料の質量に対してどの程度増減しても良いかを ユーザが決めるのである. 同様にしてコストや環境負荷量の 増減を自由に設定することも可能なので，基準材料との相対 評価でありながら, 現場の意向を最大限に考慮した材料評価 に基づく選択作業が実現できる ${ }^{20)}$.

環境負荷因子には，前章で述べたような観点で環境への影 響を定量化したデータを用いる，各要因は基礎的なデータ (数值そのものが実体を伴うもの), 有害物などの排出量デー タ(各種のデータから計算されて求まる 2 次的なもの)，お よび各種の指標 (環境への影響をある法則で数值化した目安 となるもの)にカテゴライズされており，周囲の状況や戦略 上の理由等から設計対象の環境負荷量として着目すべき負荷 因子を選んで設定する。これで CPI および EPI が計算さ れ, 設定された環境負荷因子によって自動的に適切な環境コ ストが選定されて TCV も計算が可能になる。評価結果は, 基準材料に各許容值を考慮した評価基準の值に対する各材料 の計算值を, 材料選択チャートの領域分類に準じた評価点で 提示されるので，チャートの理解も不要である.

\section{3 ツールを用いた評価例一HDD のヘッドアームー}

Table 2 にツールを用いた材料選択の例を示す。ここでは
アンダーラインの部分に関する評価のみ提示するＨDD (ハードディスクドライブ)のような精密機械では振動に対す る安定性能は極めて重要である。システム構成の制約から アームは軽く，薄くなければならない。この時たわ久振動が クリティカルな固有振動数 $f$ を与えるので，この值が十分に 高いことが要求される ${ }^{28)}$ 。したがって，表のような要求が 設計者に与えられ，ツールのメニューに沿って必要項目をチ ェックすると Fig. 6 に示されるような評価グラフが提示さ れる，上部に条件設定内容が示され，以下，各材料の評価結 果がデータベース内の全材料について連続的に表示される (図は一部のみ)。各材料は，その属性を表すカテゴリーに分

Table 2 Selection criteria of materials for head arms for HDD.

- Precision component such as head arms for HDD

- Design conditions

-Section shape: $\quad$ Rectangle(Thickness free, plate), Like

-Mode of loading:

-Constraints: figures

Bending moment, Twisting moment

Stiffness (High stiffness)

Vibration (High resonant frequency) Thermal distortion (Minimum thermal

- Value conditions

-Reference material: $\quad$ Wrought ferritic stainless steel

-Allowance value:

Mass 90\%, Cost 110\%, Impact 100\%

-Environmental impact: $\quad$ Primary energy content, $\mathrm{SO}_{x}$ emission,

Resource depletion index

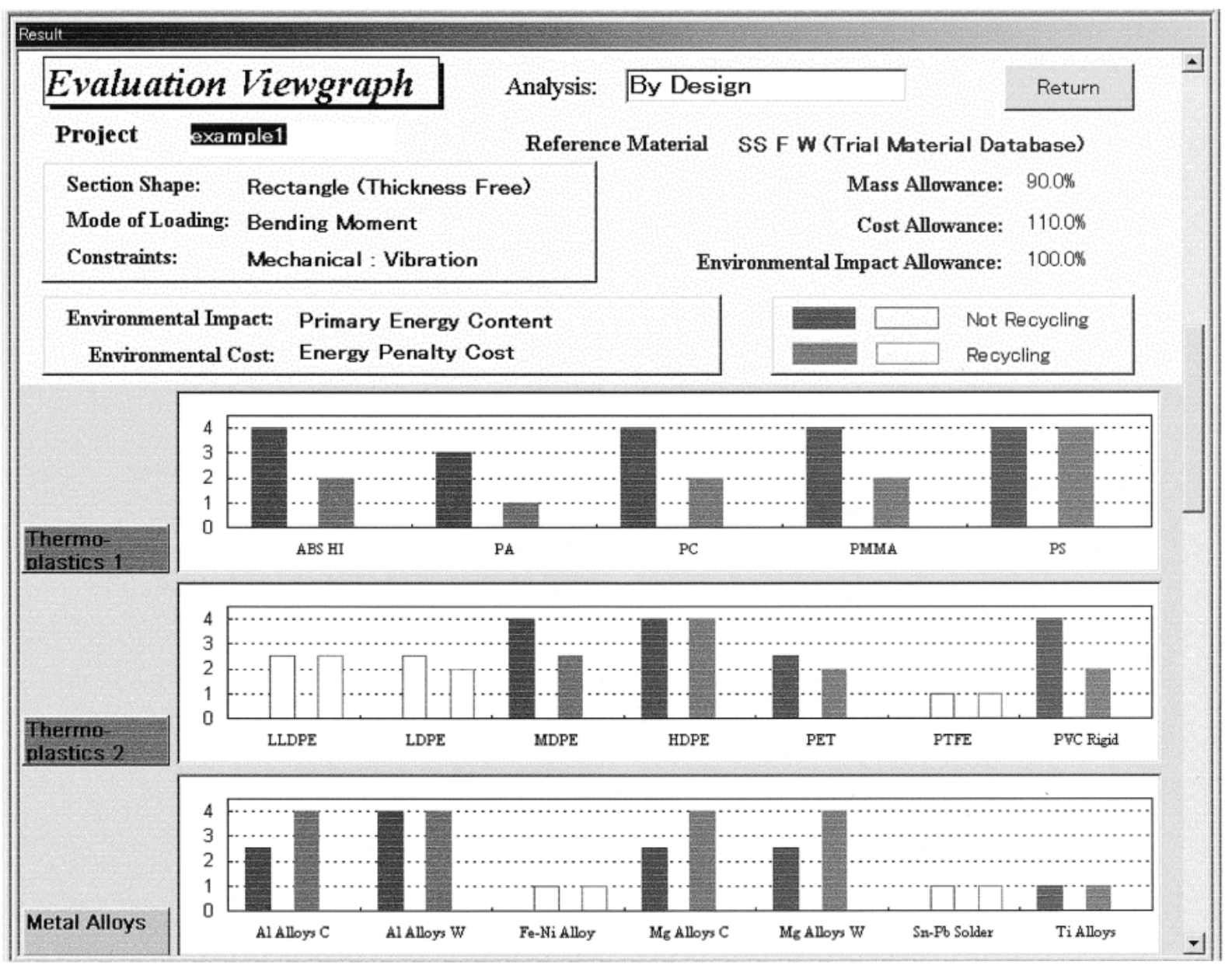

Fig. 6 Example of output from environmentally conscious materials evaluation tool (From the reference $\left.{ }^{20)}\right)$. 
類されている.

棒グラフの高さは各材料の評価点を示しており，その点数 は複合評価の領域に対して次のように付与されている．領域 $\mathrm{A}: 4$, 領域 B : 3.5, 領域 D : 3, 領域 $\mathrm{C}: 2.5$, 領域 $\mathrm{E}$ の右 半分 : 2 , 領域 $\mathrm{E}$ の左半分 : 1 . また, 0.5 点は環境調和性を 評価するのに必要な環境負荷量のデータ欠如を示し，0 点は 材料特性のデータ欠如を示している．棒グラフの色とその塗 り方はリサイクル効果を考慮するか否か，および軽量性 (も しくは材料特性，機能と制約条件の設定内容によりどちらか を示す)の優劣を示している．合金類では $\mathrm{Al}$ 合金と $\mathrm{Mg}$ 合 金が基準材料であるフェライト系ステンレス鋼に変わる候補 材料となり得ることが図に示されている.

\section{6. おわりに}

以上，コストパフォーマンスとの対比において環境調和性 を定義し，既存の材料選択方法論を発展させた「環境調和性 を考慮した材料選択方法論」とその応用，および具現化ツー ルについて報告した．方法論が確立したとはいえ，材料力学 等の構成方程式を駆使して性能指標を導出するプロセスは, 生産現場の技術者には取り組みにくい。したがって，ツール が備える性能指標の自動構成機能や評価基準の許容值設定機 能は現場での実践にとって効果的であり，使い勝手の向上と いう面でも一応の完成域に達して来ていると考えられる.

しかしながら，様々な視点で材料特性や環境への影響を評 価することはデータが整備されれば可能になったが，その多 分に相矛盾するであろう複数の評価結果を一つの意思決定に 集約する点がまだ解決されておらず，現実的には設計者ある いは開発組織の戦略に委ねる，という手段に頼らざるを得な い. 環境問題は多様で，また因果関係が曖昧な場合も多く見 られ，不確定な要素が多い。現状を正しく判断し，適切な設 計(材料選択)に結び付けていくには，因果関係に基づく精緻 な理論化よりも，多くの関連事象に基づく実用的なモデルを 迅速に構築し，既往のデータベースを活用して評価と予測を 随時実行し，的確な解決策を導出する枠組みが必要であり， 今後の材料選択における重要な課題となろう.

\section{文}

\section{献}

1) T. Sano, A. de Winter, T. Saiki, S. Horikoshi, S. Fuchizawa and S. Sado: Advanced Technology of Plasticity, Vol., Proc. 6th ICTP (1999) pp. 589-594.
2) 上野貴由, 椎野 徹, 大西 宏: 第 10 回廃棄物学会研究発表 会後援論文集, (日本廃棄物学会, 1999) pp. 135-137.

3) D. J. Harris: Building \& Environment 34(1999) 751-758.

4) 岩田光浩, 岡田英生, 大西 章, 後藤輝正 : エコデザイン 2000 ジャパンシンポジウム論文集, (エコデザイン学会連合, 2000) pp. 88-89.

5）岡本誉士夫，田中順一郎，平良繁治，柳谷和太 : 第 4 回エコバ ランス国際会議講演集, (未踏科学技術協会, 2000) pp. 67-70.

6) S. Chubbs, M. van Schaik, J. Harrington and P. Peterson : 第 4 回エコバランス国際会議講演集，（未踏科学技術協会，2000） pp. 87-90.

7) 蔵川 圭, 桐山孝司, 山際康之 : 第 17 回設計シンポジウム講 演論文集 $(1999)$ pp. 88-95.

8) 永田勝也, 愛澤政仁, 浅岡 健: エコデザイン 2000 ジャパン シンポジウム論文集，（エコデザイン学会連合，2000） pp. $188-191$.

9) 伊坪徳宏, 稲葉 敦: エコデザイン 2000 ジャパンシンポジウ ム論文集，（エコデザイン学会連合，2000）pp. 202-205.

10) J. P. Rombouts, F. W. Jansen and J. A. M. Remmerswaal : 第 4 回エコバランス国際会議講演集，（未踏科学技術協会，2000) pp. 71-74.

11）佐野 奨, 松野路雄, 市川牧彦: 太平洋セメント研究報告 138(2000) 16-23.

12) 中野加都子, 三浦浩之, 和田安彦：環境科学会誌 $13(2000)$ $141-153$.

13) M. F. Ashby: Acta Metall. 39 (1991) 1025-1039.

14) M. F. Ashby: Materials Selection in Mechanical Design, (Pergamon Press, Oxford, 1992). 邦訳) 金子純一，大塚正久：機械設 計のための材料選定，（内田老鶴圃，1997）.

15) M. F. Ashby: Am. Soc. Test. Meas. Standard Technical Publication 1311 (1997) pp. 45-62.

16) P. M. Weaver, M. F. Ashby, S. C. Burgess and N. Shibaike: Materials \& Design 17 (1996) 11-17.

17）芝池成人，浅野隆宏：第 8 回設計工学・システム部門講演会講 演論文集，（日本機械学会，1998）pp. 469-472.

18）芝池成人, 浅野隆宏, 走田利春, 川井春夫 : Matsushita Tech J 45 (1999, June) 130-137.

19）芝池成人，浅野隆宏，M. F. Ashby：エコデザイン 99 ジャパ ンシンポジウム論文集, (エコデザイン学会連合, 1999) pp. 96-99.

20）芝池成人：エコデザイン 2000 ジャパンシンポジウム論文集, (エコデザイン学会連合, 2000) pp. 52-55.

21) M. F. Ashby: Phys. Status. Solidi. (a) 131 (1992) 625-638.

22) M. F. Ashby: Materials Selection in Mechanical Design 2nd Edit., (Butterworth-Heinemann, Oxford, 1999).

23) Cambridge Materials Selector Ver. 2.0, (Granta Design, Cambridge, 1994).

24) I. Boustead and G. F. Hancock: Handbook of Industrial Energy Analysis, (Ellis Horwood, Chichester, 1979).

25) BUWAL: Life Cycle Inventories for Packagings, (Swiss Agency for the Environment, Forests and Landscape, 1998).

26) IDEMAT '98, (Delft University of Technology, Delft, 1998).

27) JEMAI-LCA, (産業環境管理協会, 2000).

28) D. Cebon and M. F. Ashby: Meas. Sci. \& Tech. 5(1994) 296306.

29) M. F. Ashby and D. Cebon: Case Studies in Materials Selection, (Granta Design, Cambridge, 1996).

30) Cambridge Engineering Selector Ver. 3.0, (Granta Design, Cambridge, 1999).

31) FUZZYMAT 2.0, (SNC Bassetti et Isaac, Grenoble, 1995).

32) 吉川弘之 : ILLUME 4(1992) 41-56. 